libertarian analysis of the freedom of will includes reservations-it disappoints the reader who may well have been led by the excellence of the first two parts to expect an equally lucid exposition of the nature of the free society and the conditions on which such a society can exist.

Such an exposition Mr. Cranston could undoubtedly give us, and his indication of the contribution which the philosopher could make to clear thinking and constructive debate induces the hope that he may still attempt it. He has shown us plainly that, without clear ideas of the meaning of freedom, confusion and misunderstanding are inevitable and to that extent stimulate the careful examination which should form the basis for any firm defence of academic freedom and opposition to the invasion of civil rights, both in the Civil Service and in technical fields like that of atomic energy. But on the issue of responsibility and the choice of freedom, Mr. Cranston says little, though his clarity of thought and his avoidance of jargon suggest that he could write much that would help the layman as well as the professional philosopher.

"Parliamentary institutions, with their free speech and respect for the rights of minorities, and the inspiration of a broad tolerance in thought and its expression-all this we conceive," said Her Majesty the Queen, in her Coronation Day broadcast, "to be a precious part of our way of life and outlook." If all this is to be cherished and practised, much more is required than the formulation and observance of the appropriate rules and organizations with which Mr. Brewer's book is concerned. We must have clear understanding of what we mean by freedom in the political and social context of our time, and of the conditions under which those freedoms which we wish to cherish are best nourished. Our defence of intellectual freedom - the right of investigation and of communication in whatever aspect-can only be securely based on a like clear understanding of the whole situation, and its philosophical, no less than its practical, implications.

\section{FROEBEL'S INFLUENCE ON ENGLISH EDUCATION}

Friedrich Froebel and English Education

By P. Woodham-Smith, J. P. Slight, O. B. Priestman, H. A. Hamilton, N. Isaacs. Edited by Evelyn Lawrence. Pp. 248+12 plates. (London: University of London Press, Ltd., 1952.) 20s. net.

$\mathrm{T}$ HE purpose of this book, to make a faithful record of the development of Froebel's educational concepts in relation to English education over the past century, is carried out with admirable objectivity. As the story unfolds, it is brought home to us that much which we tend to think of as specifically the pressing problem of our times is inherent in progressive education at all times.

The expansion of Froebel's ideas is traced through chance factors of ideas, social problems and, above all, the type of disciple he inspired. Froebel's own ardent mind, always seeking hidden connexions, underestimating his powers of suggestion, impatiently generalizing from insufficient data and imploring educationists to show greater respect for childhood, fired the imagination of the singularly fine quality of women who were struggling for emancipation all over the world; the German Baroness von Marenholtz, the Indian Pundita Ramabai, the headmistresses of such outstanding schools as Notting Hill and Croydon High Schools and the North London Collegiate, the stepdaughter of the first Mistress of Girton and many others incorporated the idea of the emancipation of children in their own campaign. Outstanding men, such as Dickens, gave the idea critical and appreciative attention. Froebel's enthusiasm had first been roused by the international group of young men he met in Pestalozzi's school, and the international appeal of the ideas resulted in kindergartens opening in countries far beyond Europe; moreover, contact was maintained between the work in different countries-for example, the British interest in the American developments under Dewey.

The story is told of Froebel's pioneering, how he saw play as an activity as purposeful as work and revolutionized the child-adult relationship, supplanting repression with encouragement and making fellow teachers and learners of both. His reason for concentrating on the very young was merely that he saw this age, denied the sacred right of discovery, as the weakest link in the vital chain of development. $\mathrm{H}_{\Theta}$ begged for no slavish following of his suggestions and, in order to minimize this, had to attend to the training of educators. The story is told of the ceaseless fight for training teachers in freedom, in order to preclude misuse of practice through misconception of principles, and how this led to a much finer quality of teacher for the very young than had previously been thought necessary. Although certain restrictions in government schools meant that the kindergartens had to be privately run, the spiritual basis of the work and the sense of vocation in the training convinced the Froebel teachers that their ideas concerned all children, and the story is laced with accounts of out-of-school activities and club work. Societies had to be formed to maintain standards, encourage pioneering and prepare public opinion.

The chapter on Froebel's religious philosophy is tackled on too narrow a field, since it fails to throw light on the international inter-religious appeal of his spiritual concepts. It is generally accepted that he was an unsystematic philosopher and that he, like some of the earlier psychoanalysts, mistakenly believed childhood tensions could be entirely eliminated; but there is grandeur in this misconception when we realize that it was arrived at through surmounting the most terrible tensions in his own childhood, and we have far to go before we have eliminated unnecessary suffering in children.

The final chapter is one of the finest expositions yet written of the principles underlying modern educational practice. The style is clear and temperate, and the survey, though brief, is very extensive. Froebel's principles are formulated systematically, and attention is directed to recent results from studying children, which are related to our changed picture of the world. In conclusion, there is a thoughtprovoking study of the nature of unresolved clashes in ultimate philosophies and a new approach to the problem of freedom of thought which virtually compels us to take on the responsibility of granting children their right to be prepared for the responsibility of freedom. If we act quickly, we may still be in time to save the human race by emancipating the children.
P. M. Pickard 